\title{
Analogi Mesin untuk Model Produktifitas Pribadi
}

\author{
Rio Aurachman ${ }^{1}$ \\ ${ }^{1}$ Telkom University, Bandung, Indonesia \\ E-mail: rioaurachman@telkomuniversity.ac.id
}

Received 26 Oktober 2020

Accepted for publication 26 Oktober 2020

Published 26 Oktober 2020

\begin{abstract}
Manusia memiliki waktu hidup 24 jam dalam sehari. Tetapi dari 24 jam tersebut tidak seluruh waktunya memiliki makna. Perlu Suatu cara agar dalam 24 jam kehidupan manusia bisa terus berkarya dan bermanfaat. Salah satu kata kuncinya adalah motivasi.
\end{abstract}

Keywords: Produktifitas, Motivasi

\section{Pendahuluan}

Manusia memiliki duraasi kehidupan yang terbatas. Hanya 24 jam dalam sehari. Dalam setahun hanya 365 hari. Dalam satu kehidupannya mungkin di kisaran waktu tidk sampai 100 tahun. Menjadi suatu pertanyaan, bagaimana manusia bisa mengisi kehidupannya sehingga tetap bermanfaat

Hal itu tiak terlepas dari filosofi yang dianut oleh manusia. Filosofi tersebut mencakup tujuan hidupnya. Maka suatu kegiatan dianggap produkti, bermanfaat, dan berguna tergantung apakah menunjang tujuan tersebut atau tidak. Sebagai contoh, tujuan hidup manusia adalah ibadah kepada Tuhan [1].

Seringkali tujuan yang dicapai adalah sesuatu yang belum tergapai. Hal tersebut menimbulkan gap. Karena ada gap, tentu butuh kemampuan dan usaha manusia untuk bisa menutup gap tersebut.

Diperlukan suatu rangkaian kegiatan dan aktivias untuk bisa mencapai tujuan dan menutup gap. Kegiatan dan aktivitas memerlukan sumber daya dan energi untuk bisa dikerjakan dan dilakukan. Sebagai manusia, selain energi dari fisik, diperlukan juga energi dari jiwa yaitu sebentuk motivasi untuk mengerjakan.

\section{Pembahasan}

Salah satu pertanyaan penting yang perlu dijawab adalah bagaiamana menjaga motivasi tersebut. Pertanyaan lain yang perlu dijawab adalah saat sudah motivasi maka perlu melakukan apa?

Dua hal terpenting dalam menjag produktifitas adalah motivasi untuk melakukan dan kejelasan apa yang dilakukan. Hal itu dapat diilustasikan seperti sebuah mesin. Agar mesin dapat terus produktif, maka mesin tersebut perlu mendapatkan masukan sumber daya yang dapat mendorong terjadinya gerak. Mesin memerlukan pasokan energi.

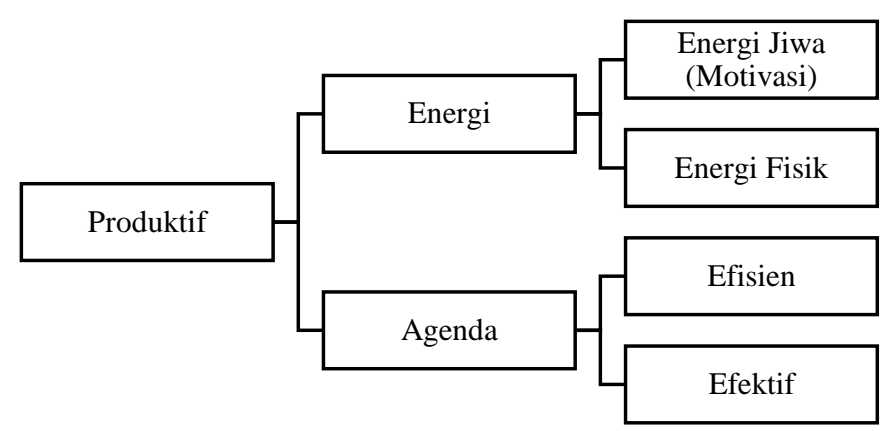

Gambar 1 . Model Produktifitas

Setelah ada energi untuk melakukan, maka mesin tersebut perlu memiliki sebuah sistematika untuk mentransformasi energi yang didapatkan menjadi suatu bentuk energi lain. Sebagai contoh mesin motor akan mengubah energi listrik menjadi energi gerak. 
Hal yang sama juga terjadi pada manusia. Untuk dapat produktif manusia membutuhkan energi yang dapat membuatnya bekerja. Kemudian energi tersebut ditransformasi menjadi bentuk energi lain dalam bentuk kegiatan dan aktivitas. Sebagai contoh saat seseorang menggunakan energi untuk beribadah, maka energi yang digunakan akan ditransformasi menjadi pahala.

Gambar 1 menunjukkan bagaimana produktifitas dapat terbentuk. Besar energi yang dikeluarkan dan ukuran ketercapaian akan menhasilkan angka produktifitas.

\section{Penutup}

Menggunakan model ini, untuk menjadi seseorang yang produktif perlu memiliki energi dan agenda. Energi meliputi dua hal yaitu energi fisik dan energi jiwa (Motivasi).

Seseorang yang memiliki energi, juga tidak akan mampu produktif bila tidak memiliki agenda. Energi tidak akan tersalurkan. Agenda tersebut harus memiliki dua sifat, efektif dan efisien. Efektif memiliki makna bahwa agenda memang menunjang tercapainya tujuan[2]. Efisien memiliki makna bahwa agenda tersebut membeirkan hasil yang sebesarbesarnya dengan penggunaan energi sesedikit mungkin[2].

Di atas itu semua, individu harus memiliki tujuan yang jelas. Tanpa tujuan yang jelas, agenda tidak dapat dirancang dengan tepat. Tanpa agenda yang tepat, energi akan terbuang secara percuma.

\section{References}

[1] A. Ali, Al-Qur'an. Princeton University Press, 2001.

[2] H. Daellenbach, D. McNickle, and S. Dye, Management Science. 2012. 